\title{
Identifying biological affinities of Holocene northern Iberian populations through the inner structures of the upper first molars
}

\author{
Beatriz Gamarra ${ }^{1,2}$ (1) Marina Lozano ${ }^{1,2} \cdot$ Antonietta Del Bove $^{2,1} \cdot$ M. Eulàlia Subirà ${ }^{3} \cdot$ Manuel Edo $^{4,5}$. \\ Concepció Castellana ${ }^{4}$. Josep Maria Vergès ${ }^{1,2}$. Juan Ignacio Morales ${ }^{1,2,6} \cdot$ Artur Cebriàa $^{6} \cdot$ F. Xavier Oms ${ }^{6}$. \\ Carlos Tornero $^{1,2} \cdot$ Anna Gómez-Bach ${ }^{7}$
}

Received: 21 July 2021 / Accepted: 27 December 2021 / Published online: 3 February 2022

(c) The Author(s) 2022

\begin{abstract}
Neolithisation was a relatively fast process that affected both the interior and coastal zones of the Iberian Peninsula, but it was also a heterogeneous process that had diverse impacts on genomic and cultural diversity. In the Late Neolithic-Chalcolithic, a change in funerary practices, cultural material and trade networks occurred, and genomic heterogeneity decreased, suggesting human mobility and genetic admixture between different Iberian populations. Dental morphology has emerged as an effective tool for understanding genomic variability and biological affinities among ancient human populations. But, surprisingly, less attention has been paid to the morphological traits of inner dental tissues in Holocene European populations and their utility for the study of population dynamics. We applied 3D geometric morphometric methods on the enamel-dentine junction (EDJ) of the first upper molars to explore the biological affinities of north-eastern Iberian Peninsula populations from the Late Neolithic-Chalcolithic to the Bronze Age. Our results show that the EDJ morphologies of the northern Iberian Peninsula populations were generally homogeneous, indicative of genetic admixture as a result of human mobility and exchange networks. However, differences in the EDJ traits in remains from the Can Sadurní site are indicative of distant biological affinities with nearby populations. Additionally, the hypocone associated dentine area and the position of the trigon dentine horns relative to each other on the occlusal surface best describe the variability found among the samples studied. This study highlights the utility of EDJ morphology as a genetic proxy in Holocene population dynamic studies when paleogenomic studies are absent.
\end{abstract}

Keywords Late Neolithic-Chalcolithic · Iberian Peninsula · Enamel-dentine junction · 3D geometric morphometrics · Upper molar

Beatriz Gamarra

beagamarra@gmail.com

1 Institut Català de Paleoecologia Humana i Evolució Social (IPHES-CERCA), Zona Educacional 4, Campus Sescelades URV (Edifici W3), 43007 Tarragona, Spain

2 Departament d'Història i Història de l'Art, Universitat Rovira i Virgili, Avinguda de Catalunya 35, 43002 Tarragona, Spain

3 Unitat d'Antropologia Biològica, Departament BABVE, Facultat Biociències, Universitat Autònoma de Barcelona, 08193 Bellaterra, Spain

4 CIPAG, Col-lectiu per a la Investigació de la Prehistòria I l'Arqueologia de Garraf-Ordal. , Passeig de l'Església, 1, 08859 Begues, Barcelona, Spain
5 Institut d'Arqueologia, Universitat de Barcelona, Gran Via de Les Corts Catalanes, 585, 08007 Barcelona, Spain

6 Seminari d'Estudis i Recerca Prehistòriques (SERP), Secció de Prehistòria i Arqueologia, Department Història i Arqueologia, Universitat de Barcelona, C/ Montealegre 6-8, 08001 Barcelona, Spain

7 Departament de Prehistòria, Edifici B Facultat de Filosofia i Lletres, Universitat Autònoma de Barcelona, 08193 Bellaterra, Spain 


\section{Introduction}

Agriculture reached the Iberian Peninsula (IP) around $5,600-5,500$ cal BC, during what is known as the Early Neolithic (ca 5,600-4,800 cal BC) (Gibaja et al. 2010; Martins et al. 2015; Oms et al. 2016; Peña-Chocarro et al. 2018; Edo et al. in press). The neolithisation process in the IP was a relatively fast event that reached both the interior and the coastal zones (Aubán et al. 2018; Oms et al. 2018; RojoGuerra et al. 2018). However, it was a heterogeneous process with incoming populations exerting different impacts on the various areas of the peninsula (Hervella et al. 2012; García-Martínez de Lagrán et al. 2018). This heterogeneity is reflected in cultural and funerary practices throughout the Neolithic period, and particularly in the north-eastern (NE) IP. The Middle Neolithic (or Middle Neolithic I; ca 4,100-3,500 cal BC; Oms et al. 2016) in the NE-IP was characterised by notable regionalisation, evident in the variety of funerary practices (e.g. Castany 2008; Gibaja et al. 2010; Roig et al. 2010; Subirà et al. 2016), as well as the presence of extensive exchange networks established between groups in the western Mediterranean (Blasco 1996; Villalba et al. 2011; Borrell and Bosch 2012; Bosch et al. 2012; Weller and Fíguls 2012; Edo et al. 2012; Gibaja et al. 2013; Terradas et al. 2014; Gibaja et al. 2018), which reflects the economic strength of this period (Cebrià et al. 2013). However, by the Late Neolithic-Chalcolithic period (ca 3,500-2,300 cal BC; Oms et al. 2016), this system had collapsed, leading to both cultural and socioeconomic consequences (Martin 2003; Gibaja et al. 2010; Cebrià et al. 2013; Subirà et al. 2016). Changes in funerary practices occurred in the NE-IP, ranging from inhumations of one or two individuals-either in pit burials (also known as sepulcres de fossa) or cists (stone boxes)—during the Middle Neolithic to collective burials, mostly in caves (Cebrià et al. 2013; Martin 2003; Daura et al. 2015; Gómez et al. 2008). Settlement and subsistence patterns and cultural material also underwent changes during this period (Martin 2003), suggesting the disappearance of some of the exchange networking that took place in the previous period (Oms et al. 2016). Ancient DNA (aDNA) analyses of Iberian specimens have shown signs of incoming populations in the peninsula throughout the entire Neolithic period (Hervella et al. 2012; Olalde et al. 2015; Szecsenyi-Nagy et al. 2017). These studies also evidence a decrease in genomic diversity beginning in the Late Neolithic-Chalcolithic and continuing into the Early Bronze Age $(2,200-1,500 \mathrm{BC})$, suggesting human mobility and genetic admixture between different Iberian populations (SzecsenyiNagy et al. 2017; Olalde et al. 2018).

Although recent aDNA methods have successfully overcome the challenges DNA preservation in warm climates such as that of the Mediterranean (Olalde et al. 2019;
Fernandes et al. 2020), preservation remains an issue in larger sample sizes from ancient periods. Moreover, human remains found in particular funerary contexts are often fragmented, burned and commingled, which leads to further difficulties in their genetic analysis. In such fragmentary contexts, teeth take on increase significance, as their strong genetic component (Scott and Turner 2008) makes them an effective genetic proxy, their traits remain unchanged over time, and they are abundant in the archaeological record (Hillson 2005).

Dental morphology analyses have been employed in multiple studies to interpret the phylogenetic relationships between different species in the human lineage and the variability of living human populations (e.g. Benazzi et al. 2011, 2012; Delgado et al. 2019; Gómez-Robles et al. 2012; Martin et al. 2017; Martinón-Torres et al. 2006; Rathmann and Reyes-Centeno 2020; Skinner et al. 2008a, 2016). They have contributed to our understanding of affinities among ancient human populations by establishing historical and biological relationships between different human groups (Cucina et al. 1999; Irish and Joel 2005; Coppa et al. 2007). Dental morphology studies of prehistoric human populations in the IP are scarce and tend to focus on non-metric dental traits (Ruiz et al. 2012; Scott et al. 2013; Ceperuelo et al. 2014; Horwath et al. 2014; Subirà et al. 2016; López-Onaindia and Subirà 2017; López-Onaindia et al. 2017). Some of these studies have shown biological homogeneity in some Neolithic and Late Neolithic-Chalcolithic populations in NE-IP (Subirà et al. 2016), while others not (López-Onaindia et al. 2017). However, the biological affinities in the NE-IP, specifically in Late Neolithic-Chalcolithic transition populations, remain unclear and require further analysis to fully comprehend them.

\section{Geometric morphometrics on the enamel-dentine junction as a dental morphology proxy}

In recent years, high resolution imaging techniques have enabled researchers to noninvasively explore detailed tooth morphology and to analyse the inner structure of both fossil and living human dentitions (Skinner et al. 2010; Prado-Simón et al. 2012; Smith and Olejniczak 2012; Fornai et al. 2016; Hublin et al. 2017). Major aspects of crown morphology, such as the number and size of cusps, are influenced by genetic, epigenetic and environmental factors (see Townsed et al. (2012) for an overview). Although there is strong evidence of the genetic component during odontogenesis (e.g. Scott and Turner; Scott et al. 2018), environmental and developmental effects may not be underestimated to the contribution to the final phenotype (Riga et al. 2014). Dental morphogenesis is explained 
by the morphodynamic model (Jernvall and Jung 2000; Salazar-Ciudad and Jernvall 2002). Small changes in gene expression and signalling protein activity affecting the timing and position of the specialised inhibitors-activator signalling centres (enamel knots) during tooth morphogenesis have been shown to affect final crown morphology (Salazar-Ciudad and Jernvall 2002, 2010), and particularly with the last-forming dental traits (Riga et al. 2014; Paul et al. 2017). The distribution of these enamel knots in the inner enamel epithelium during early tooth crown formation is what ultimately shapes the folded configuration of the basement membrane (Jernvall and Jung 2000). Many features of the tooth crown originate in this membrane, which is preserved in mature teeth as the enamel-dentine junction (EDJ) prior to enamel deposition and is primarily responsible for external crown morphology (Butler 1956; Skinner et al. 2008b; Morita et al. 2014). Interestingly, the EDJ has proved a useful proxy for worn teeth in the study of taxonomic differences among some primate and Homo taxa (Skinner et al. 2008a, 2010; Ortiz et al. 2017; Hanegraef et al. 2018) as well as in living human populations. This has made it possible to increase the sample size in dental morphology studies (Smith et al. 2006; Monson et al. 2020). Additionally, the EDJ has been found to vary according neutral evolution resulting from genetic drift and migration patterns, thus reflecting past human history and population dynamics (Monson et al. 2020). However, environmental and developmental effects are also likely expected to affect EDJ, as mentioned above. Three-dimensional (3D) geometric morphometric (GM) approaches have captured shape differences in morphological traits of the EDJ through landmark/semilandmark data in living humans and our closest relatives (e.g. Skinner et al. 2010; Polychronis and Christou 2013; Al-Shahrani et al. 2014; Morita et al. 2014; Fornai et al. 2015, 2016; Martin et al. 2017; Zanolli et al. 2018; Krenn et al. 2019). GM methods constitute an especially useful technique for describing spatial aspects of morphological variation, as well as for directly visualising shape differences (Zelditch et al. 2012; Adams et al. 2013). Surprisingly, phenotypic variability in the EDJ has scarcely been examined in any prehistoric European population after the adoption of agropastoralism (Gamarra et al. 2020; Le Luyer et al. 2016; Le Luyer and Bayle 2017).

This study makes unprecedented use of the EDJ morphology of the first upper molars to analyse biological affinities between prehistoric human populations of the NE-IP associated with socioeconomic transitions and genetic admixture. Specifically, and assuming a strong genetic component for EDJ (Monson et al. 2020), we aim to confirm the decrease in genetic variability detected during the Late Neolithic-Chalcolithic period and demonstrate the use of the EDJ as a genetic proxy in population dynamic studies of prehistoric populations.

\section{Materials and methods}

\section{Materials}

We selected 23 upper first molars $\left(\mathrm{M}^{1}\right)$ from NE and central IP sites dated from the Late Neolithic-Chalcolithic to the Bronze Age, although we were only able to analyse 16 samples (Fig. 1 and Online Resource 1). The upper first molar was selected because it is the most stable tooth in the permanent molar row (Butler 1939; Dahlberg 1945; Townsend et al. 2009; Morita et al. 2014; Paul et al. 2017). Since crown formation begins in utero (Kraus and Jordan 1965; Hillson 1996), the upper first molar is less susceptible to environmental influences than later-forming teeth in the molar row (Paul et al. 2017; Monson et al. 2020), and therefore more directly reflects the individual's underlying genotype (Paul et al. 2017). The selected teeth presented well-preserved, complete crowns, with well identified cemento-enamel junctions (CEJ). The molars showed a degree of wear equal to or less than 3 on Molnar's scale (Molnar 1971). Samples with cracks and damage on the crown dentine (see below for micro-CT acquisition) were excluded from morphological analyses. Since morphological asymmetry tends to be minor among dental antimeres (Scott and Turner 1997, GómezRobles et al. 2007), it is a common practice in studies of inner dental crown tissues to select both right and left $\mathrm{M}^{1}$ (e.g. Le Luyer 2016; Martin et al. 2017; Zanolli et al 2018). The teeth selected were either on the maxilla in situ or isolated. When isolated, and in order to maximise the sample size, no discrimination was made between the right and left molars. However, only the side with the highest number of samples was chosen for each site in order to ensure a single tooth per individual. When both molars were present (in the maxilla), the better-preserved tooth was selected. Details on sample composition and wear degree are given in Table 1.

\section{Micro-CT image acquisition and image processing}

The samples were scanned using two scanners housed at Centro Nacional de Investigación sobre la Evolución Humana (CENIEH) facilities, in Burgos (Spain). Most of the samples were scanned using a VITomelX s $240 \mu$-CT from GE Sensing \& Inspections Technologies. Scans were performed with a $0.2-\mathrm{mm}$ copper filter and a filament voltage of $150 \mathrm{kV}$, a current of $150 \mu \mathrm{A}$ and an acquisition time of $500 \mathrm{~ms}$. Output images were then processed with a median and a ring artifact filter to improve image contrast and reduce noise. The resultant output images had a voxel size ranging between 20 and $25 \mu \mathrm{m}$ for isolated teeth and teeth included 


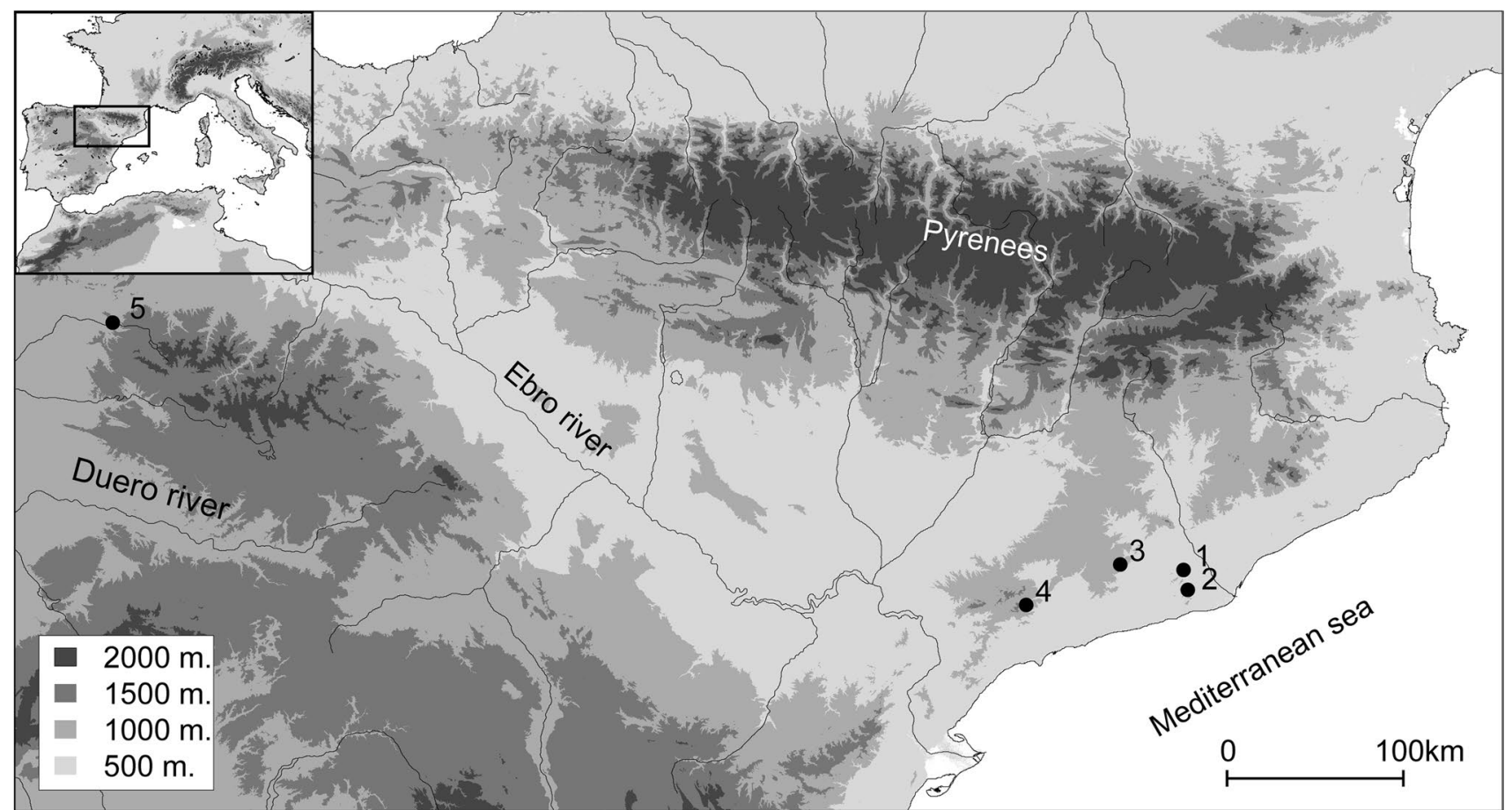

Fig. 1 Map showing the location of the sites employed in this study. Archaeological sites: 1: Cova de les Agulles, 2: Cova de Can Sadurní, 3: Cova de la Guineu, 4: Cova dels Galls Carboners, 5: Cueva de
El Mirador. Generic Mapping Tools 4.5.13 (Wessel and Smith 1998) and the topographic ETOPO data set (Amante and Eakins 2009) was used to create this map

Table 1 List of the samples employed in this analysis. Wear stage according to Molnar (1971)

\begin{tabular}{llllll}
\hline Site & ID & Skeletal remains & M1 & Wear stage & Horn tips reconstructed \\
\hline Cueva de El Mirador & MIR203_S36_151 & Skull & R & 3 & Protocone, paracone, hypocone \\
& MIR202_N39_24 & Skull & L & 3 & Protocone, paracone, metacone, hypocone \\
& MIR202_P38_45 & Skull & L & 3 & Protocone, paracone \\
& MIR202_T35_7 & Skull & L & 3 & Protocone, paracone \\
& MIR201_P37_162 & Isolated & R & 0 & \\
& MIR201_P37_164 & Isolated & R & 1 & Protocone, paracone, metacone \\
Cova dels Galls Carboners & MIR201_REM_502 & Maxilla & L & 3 & \\
Cova de Can Sadurní & GC_209 & Isolated & L & 0 & \\
& 02CS-D9-If-9.114 & Isolated & L & 0 & Protocone \\
& 02CS-E10-Ie-9.62 & Isolated & L & 0 & \\
C1CS-F5-Ic 813 & Isolated & L & 1 & Protocone, paracone \\
& 02CS-E7-Ie-9.348 & Isolated & L & 3 & \\
Cova de la Guineu & GN95_REM_4 & Isolated & R & 1 & \\
& GN95_REM_7 & Isolated & R & 0 & \\
& Gn-M-1 & Skull & L & 3 & R \\
\hline
\end{tabular}

in maxillary fragments, and between 60 and $91 \mu \mathrm{m}$ when teeth were isolated from cranium scans. Some of the samples from El Mirador cave were scanned using a Scanco Medical AG Micro-Computed Tomography 80. Scans were taken using two $0.1 \mathrm{~mm}$ copper filters and a filament voltage of 70
$\mathrm{kV}$, a current of $114 \mu \mathrm{A}$ and an average acquisition time of $300 \mathrm{~ms}$. The resultant slice thickness was $18 \mu \mathrm{m}$ for isolated teeth and $74 \mu \mathrm{m}$ for teeth included in maxillary fragments.

The microCT data for each sample was imported into Avizo software (version 2020.2 trial license), where dentine 
tissue was semi-automatically segmented using a 3D voxel value histogram and grayscale values (Martin et al. 2017) with manual corrections (Olejniczak et al. 2008; Le Luyer et al. 2016; Le Luyer and Bayle 2017; Zanolli et al. 2018). Due to sample variable image resolution, and in order to avoid significant effects on differential resolution on the segmentation step, we equalled image resolution among all samples by resampling the images stack of those samples presenting the highest resolution range (20 to $25 \mu \mathrm{m}$ ) to lower resolution range $(60$ and $91 \mu \mathrm{m})$. Three-dimensional (3D) surface models of the EDJ of each tooth were generated using a constrained smoothing algorithm (Le Luyer and Bayle 2017; Zanolli et al. 2018) and imported in stl format. Lastly, the EDJ 3D surface models were edited and mirrored to left molars, when the left molar was missing or unusable. For samples presenting some degree of occlusal wear (Table 1), dentine horn apices were manually reconstructed following the interpolation approach described in Zanolli et al. (2018). Digital surfaces of the EDJ 3D surface models are available on MorphoSource (see Online Resource 1 for digital object identifiers).

\section{Enamel-dentine junction shape analyses}

Viewbox 4 dHAL software, version 4.1.0.8, was used to create a template of eight landmarks and 59 curve semilandmarks to describe the EDJ surface (Table 2 and Fig. 2), following the workflow described in Bastir et al. (2019). The occlusal surface was defined by seven anatomical landmarks corresponding to the four tips of the dentine horns and three points identified on the occlusal surface (Fornai et al. 2015). Curve semilandmarks were also used to describe the marginal ridges that connect the dentine horns and other identified landmarks on the occlusal surface (Fornai et al. 2015). The cervical outline was also characterised along the CEJ with 24 curve semilandmarks. The initial landmark of the cervical outline was placed on the middle part of the buccal face of the crown (between the paracone and metacone) and continued mesially (Martin et al. 2017). Enough landmarks and semilandmarks were employed to ensure that the main morphological aspects of the EDJ were captured. The template was subsequently applied to the EDJ surface of each sample by means of a thin-plate spline (TPS) interpolation

Table 2 List of landmarks and semilandmarks employed for describing the enamel-dentine junction

\begin{tabular}{llll}
\hline Occlusal landmarks & & Occlusal curve semilandmarks \\
1 & Protocone horn tip & Mesial ridge (9) & From protocone to paracone horn tips \\
2 & Paracone horn tip & Buccal ridge (5) & From paracone to metacone horn tips \\
3 & Metacone horn tip & Distal ridge (9) & From metacone to hypocone horn tips \\
4 & Hypocone horn tip & Oblique ridge (9) & From metacone to protocone horn tips \\
5 & $\begin{array}{l}\text { Lowest point along the marginal edge } \\
\text { between protocone and hypocone horns }\end{array}$ & Hypocone ridge (3) & From hypocone horn tip to landmark 7 \\
6 & $\begin{array}{l}\text { Deepest point of the central fovea } \\
\text { Deepest point of the distal fossa }\end{array}$ & & \\
7 & & Cervical curve semilandmarks & \\
Cervical landmarks & CEJ point at the middle part of the buccal & CEJ outline (24) & \\
8 & $\begin{array}{l}\text { face of the crown (between the paracone } \\
\text { and metacone) }\end{array}$ & & \\
\hline
\end{tabular}

Fig. 2 Configuration of landmarks (red) and semilandmarks (blue) digitised on the enameldentine junction of first upper molars. See Table 2 for detailed descriptions of the anatomical landmarks
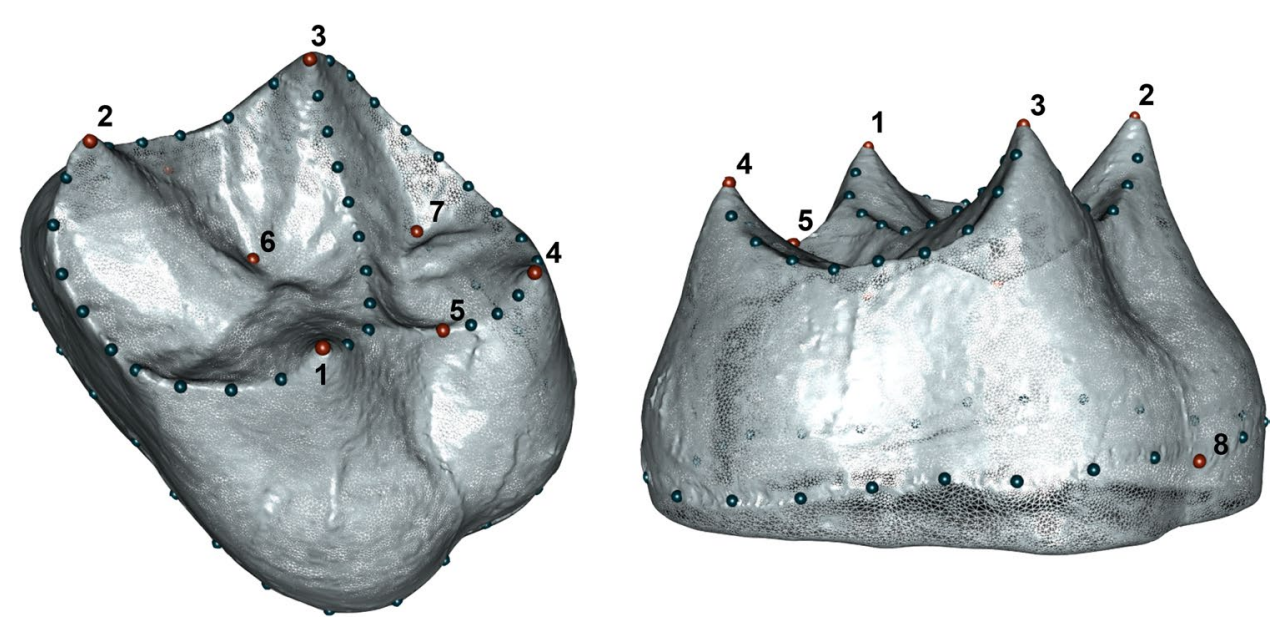
function, and projected onto the target. The semilandmarks were allowed to slide along the curve semilandmarks to minimise the TPS bending energy between each EDJ specimen and the template (Gunz and Mitteroecker 2013). After TPS interpolation, semilandmarks were treated as geometrically homologous points between individuals (Gunz et al. 2005), being able to be analysed in conjunction with landmark points (Le Luyer et al. 2016; Bastir et al. 2019; Sorrentino et al. 2020). Different landmark and semilandmark sets were compared in order to analyse which landmark and semilandmark configurations best discriminate the sample distribution in the morphometric space. The landmark and semilandmark sets corresponded to (1) all landmark and semilandmark configurations (EDJ+CER), (2) cervical landmarks and semilandmarks (CER) and (3) occlusal traits of the EDJ landmark and semilandmark configurations (EDJ).

Shape coordinates were then imported and a Generalized Procrustes Analysis (GPA) was performed using "Morpho" package in R v. 3.5.2 (R Core Team 2020), where scale, position and orientation were standardised to minimise the overall sum of the squared distances between corresponding landmarks and semilandmarks. The size measure was represented by the natural logarithm of centroid size (lnCS).

\section{Statistical analyses}

A principal component analysis (PCA) was performed on the Procrustes coordinates for all landmark and semilandmark configurations (EDJ+CER, CER, EDJ) to explore morphological variation across the sample (see Online Resource 1 for sample identifier equivalence). A column represented by the natural logarithm of centroid size (hereafter called lnCS) was added to shape coordinates in order to perform a PCA in the form space (size + shape) for all configurations (Klingenberg 2016). We applied the broken stick model (Frontier 1976, adapted from MacArthur 1957) to estimate how many principal components (PC) to retain (Online Resource 1). According to this method, we decided to use the two first PCs for graphic representation in every case using ggplot2 $\mathrm{R}$ package. We calculated the shape variations associated with the extremes of the PC scores to visualise the morphological variability of the sample analysed (Morpho, $\mathrm{Rgl}$ and Arothron R packages; Schlager 2017; Profico et al. 2018). Since normality and homogeneity of variance were not possible to test for each site (some of the sites were represented by one individual), non-parametric statistical tests were performed. Shape variation related to size (i.e. allometry) was explored by means of Spearman correlations (rho) of the PC scores against $\operatorname{lnCS}$. Site differences observed in the first two PCs were statistically tested using Kruskal-Wallis tests for all landmark and semilandmark sets in both shape and form spaces (Sorrentino et al. 2020). To assess the possible error derived from digitalising the corresponding points, a repeatability test for landmark and semilandmark placement was performed. We applied the intraclass correlation coefficient (Fisher 1958) to quantify measurement error in repeated measures, which consisted of performing one-way ANOVA on repeated measurements and employing the individual as the categorical variable (Fruciano 2016). A subset sample of five individuals was randomly chosen and landmarks and semilandmarks were digitalised three times with 1 week between iterations. Our repeatability test resulted in a $94 \%$, indicating an excellent reliability (Portney and Watkins 2009). Data were statistically analysed with $\mathrm{R}$ software.

\section{Results}

The shape and form-space PCA plots are represented in Figs. 3 and 4. The first two PCs in shape-space accounted for $43.4 \%$ of the total variance when the EDJ+CER configuration was used. Patterns of EDJ+CER surface morphology of individuals belonging to different sites were significantly different across the first PC (24.2\%) (Table 3). More specifically, all of the individuals sampled from the Can Sadurní site were distinct from the other Late Neolithic-Chalcolithic and Bronze Age sites, which appear to overlap in the shape-space (Fig. 3a). The corresponding shape change mainly involves the expansion of the distolingual dentine horn associated with the hypocone at the cervical outline and the relative position of the dentine horns associated with the trigon cusps on the occlusal surface (Online Resource 2). The distribution of the samples across the PCA shapespace shows that individuals from the Can Sadurní site tend to be associated with lower (negative) PC1 values, with a buccolingually elongated trigon area on the occlusal surface as a result of more lingually oriented horns associated with the protocone and relatively higher trigon horn tips, together with a narrower talonid area at the cervical outline and higher cervical height (distance from the ridges connecting horn tips to the cervical line; Monson et al. 2020) than the EDJ morphologies of individuals from other sites. Samples with higher (positive) PC1 values also tend to be associated with a mesio-distal elongation of the occlusal area derived from the distolingual extension of the cervical area associated with the hypocone, as well as inner located dentine horns associated with the trigon cusps. Although not been statistically significant (Table 3), samples associated with higher (positive) PC2 (19.2\%) values also tend to be associated with broader mesio-distal occlusal surfaces derived from a broader talonid occlusal area (Online Resource 3). No significant $(P>0.05)$ Spearman correlations were found for either PC's with lnCS. The inclusion of size information in the form-space PCA explains higher total variance for the first two PCs (62.1\%), and this variable was retained in PC1 (rho $=-0.99, P<0.001)$. However, PC1 (49.9\%) did not 
Fig. 3 Shape space PCA plots for a) EDJ+CER, b) CER and c) EDJ configuration (description in Material and Methods section). The deformed warped surfaces (occlusal and mesial view) of enamel-dentine junction and cervical and occlusal wireframes of first upper molar are drawn at the end of the axes to illustrate the extreme morphological trends. a)

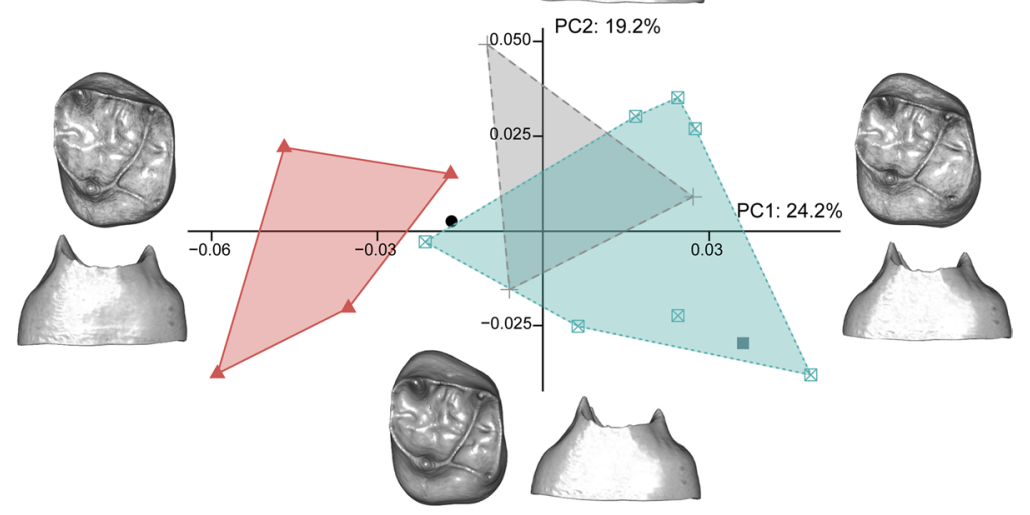

b)

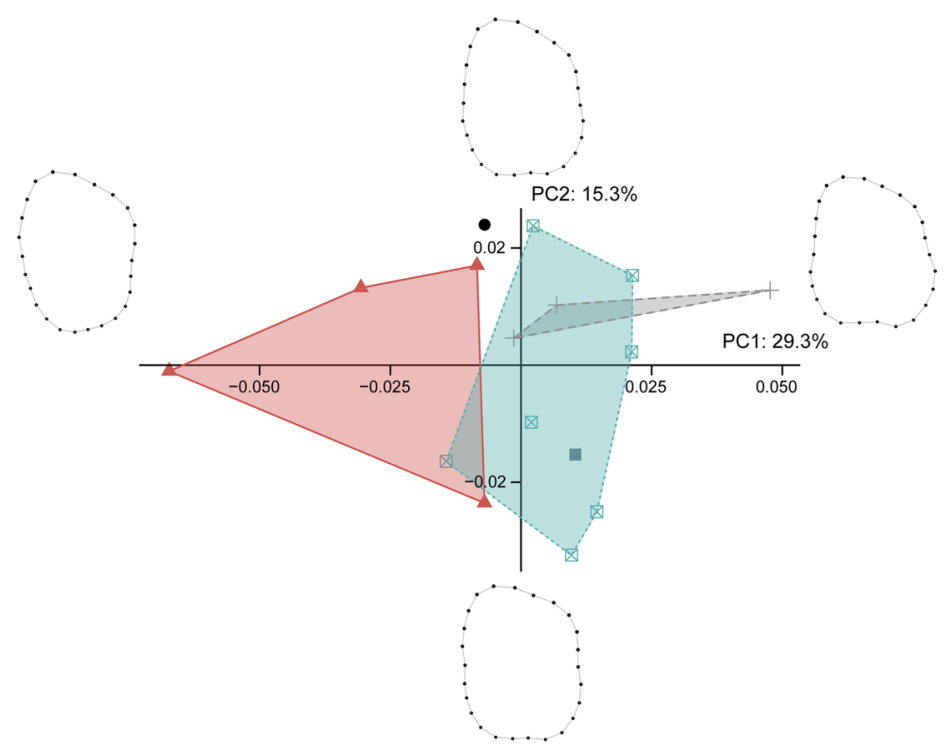

c)

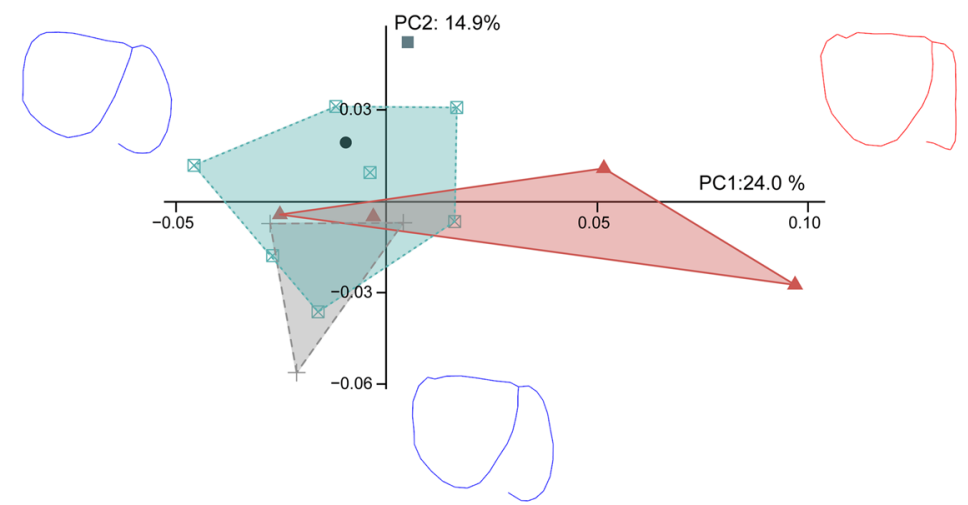

Late Neolithic - Chalcolithic

Bronze Age

$\Delta$ Can Sadurní $\quad$ Cova de la Guineu $\longrightarrow$ Cova dels Galls Carboners
@ Cueva de El Mirador Cova de les Agulles


Fig. 4 Form space PCA plots for a) EDJ+CER, b) CER and c) EDJ configuration (description in Material and Methods section). The deformed warped surfaces (occlusal and mesial view) of enamel-dentine junction and cervical and occlusal wireframes of first upper molar are drawn at the end of the axes to illustrate the extreme morphological trends

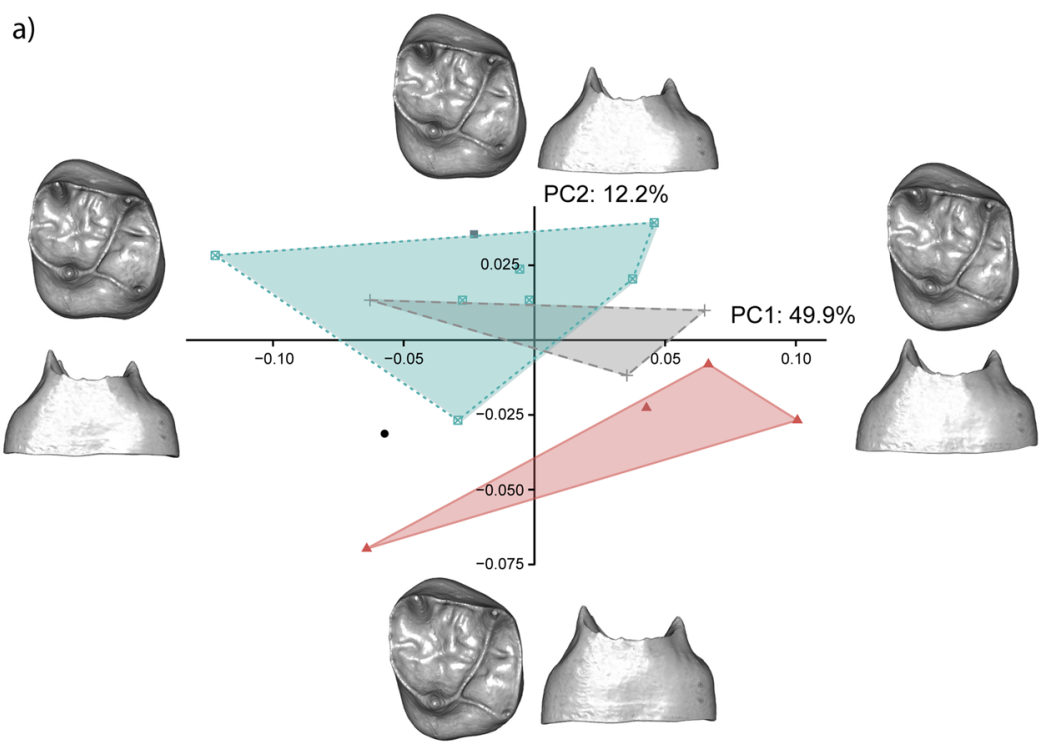

b)

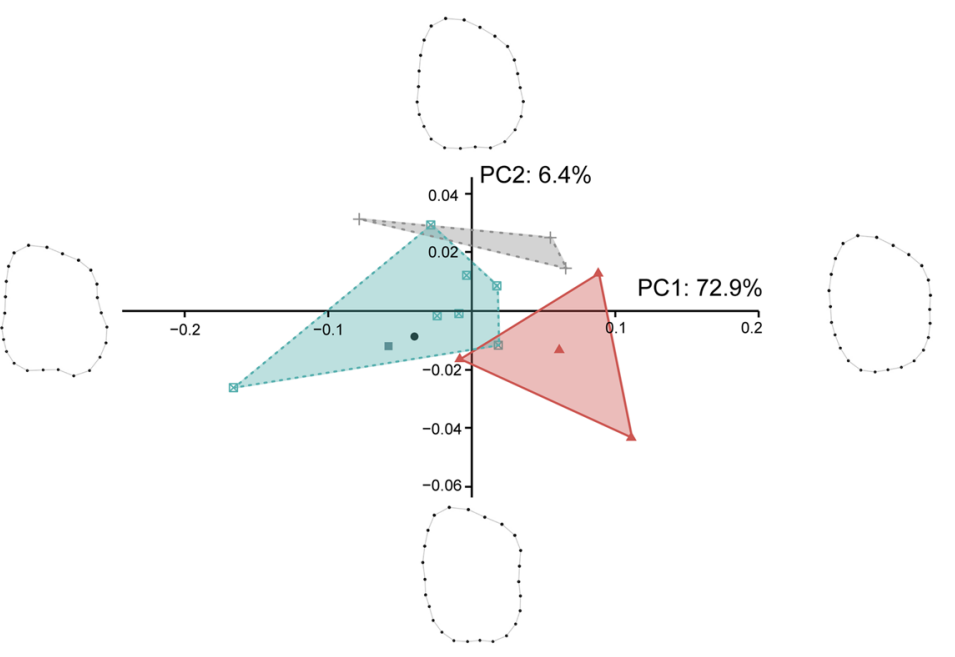

c)
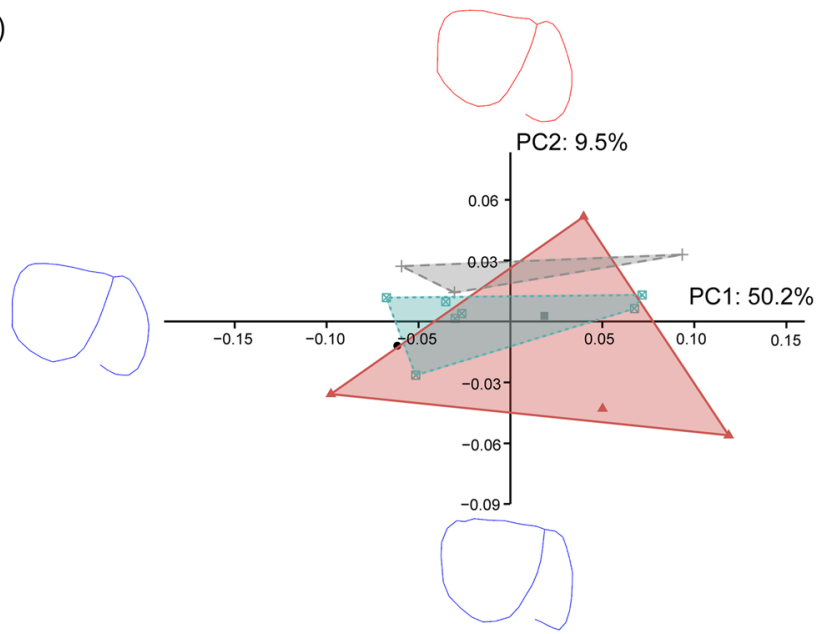

Late Neolithic - Chalcolithic

Bronze Age

Can Sadurní

Cova de la Guineu

Cova dels Galls Carboners
- Cova de les Agulles 
Table 3 Statistical results of sites difference observed along the first two PC of all landmark and semilandmark configurations in both shape and form-space PCA. Significant results $(P<0.05)$ in bold

\begin{tabular}{lllllll}
\hline & & \multicolumn{2}{l}{ Shape-space PCA } & & \multicolumn{2}{l}{ Form-space PCA } \\
\cline { 3 - 4 } \cline { 6 - 7 } & & Test & $P$-value & & Test & $P$-value \\
\hline EDJ+CER & PC1 & $X^{2}=9.782$ & $\mathbf{0 . 0 4 4}$ & & $X^{2}=2.626$ & 0.622 \\
& PC2 & $X^{2}=2.273$ & 0.685 & & $X^{2}=9.105$ & 0.058 \\
CER & PC1 & $X^{2}=8.130$ & 0.086 & & $X^{2}=6.588$ & 0.159 \\
& PC2 & $X^{2}=4.058$ & 0.398 & & $X^{2}=7.319$ & 0.119 \\
EDJ & PC1 & $X^{2}=2.979$ & 0.561 & & $X^{2}=1.873$ & 0.758 \\
& PC2 & $X^{2}=6.282$ & 0.179 & & $X^{2}=6.233$ & 0.182 \\
\hline
\end{tabular}

significantly distinguish between EDJ+CER surface morphologies of individuals belonging to different sites, though PC2 was close to significance (12.2\%) (Fig. 4a, Table 3). PC2 was not statistically correlated with $\operatorname{lnCS}$ (rho $=-0.09$, $P=0.737$ ). This means that size, represented here by the $\operatorname{lnCS}$, did not affect shape variation between individuals from different sites. Samples from different sites distributed along the PC2 tend to be associated with the same occlusal traits as the ones described for the PC1 shape-space.

When only the cervical outline was used to detect differences among the samples (CER), the two first PCs in the shape-space accounted for a similar total variance $(44.6 \%$; Fig. 3b) as for when all landmarks (EDJ-CER) were used. Although neither PC1 (29.3\%) nor PC2 (15.3\%) accounted for statistical differences between sites (Table 3), the Can Sadurní individuals tend to have smaller (negative) PC1 values. The cervical morphology distributed in smaller PC1 values is associated with mesio-distally narrower cervical outlines derived from the reduction of the lingual dentine horns in the cervical area. Additionally, most of the Can Sadurní individuals presented significantly smaller cervical outlines associated with lower PC1 values (rho=0.70, $P=0.003$ ) (Fig. 5a). No significant size correlations were found for PC2 values (rho $=-0.10, P=0.704$ ). Although the samples slightly overlap in the form-space PCA (Fig. 4b) and the two first PCs accounted for a higher total variance $(79.3 \%)$, none of them significantly differentiated the samples from different sites (Table 3). Individuals' distributions along the form-space PC1 were associated with the same cervical outline traits as in shape-space PC1, but with inverted negative and positive values. As for the EDJ+CER analysis, size information was retained in the form-space PC1 (72.9\%) (rho $=-0.99, P<0.001)$, but not in PC2 (6.4\%) (rho $=-0.023, P=0.934)$.

The distribution of individuals belonging to different sites overlaps in both shape and form-space PCAs when only occlusal traits (EDJ) were characterised (Figs. 3c and $4 \mathrm{c})$, although in the case of the space-space PCA, this overlap was caused by two individuals from Can Sadurní. The total variance is explained by the fact that the two first PCs decreased in both PCA spaces compared to previous landmark set analyses (shape-space: $38.9 \%$; form-space: $59.7 \%$ ), and no significant differences were found in any of the PCs (Table 3). Despite the lack of significance, two Can Sadurní individuals exhibited higher (positive) PC1 values, which are associated with a reduced talon area and a mesio-distally expanded trigon occlusal area. As in the CER landmark and semilandmark configurations, PC1 was significantly correlated with $\operatorname{lnCS}$ in both space analyses (shape-space: rho $=-0.57, P=0.020$; form-space: rho $=-0.96, P<0.001$ ), while PC2 was not (shape-space: rho $=0.17, P=0.512$; form-space: $r h o=-0.18, P=0.490)$ (Fig. 5b).

In all PCAs, the Bronze Age individual from the Cova dels Galls Carboners site overlaps with the Late Neolithic-Chalcolithic site distribution.

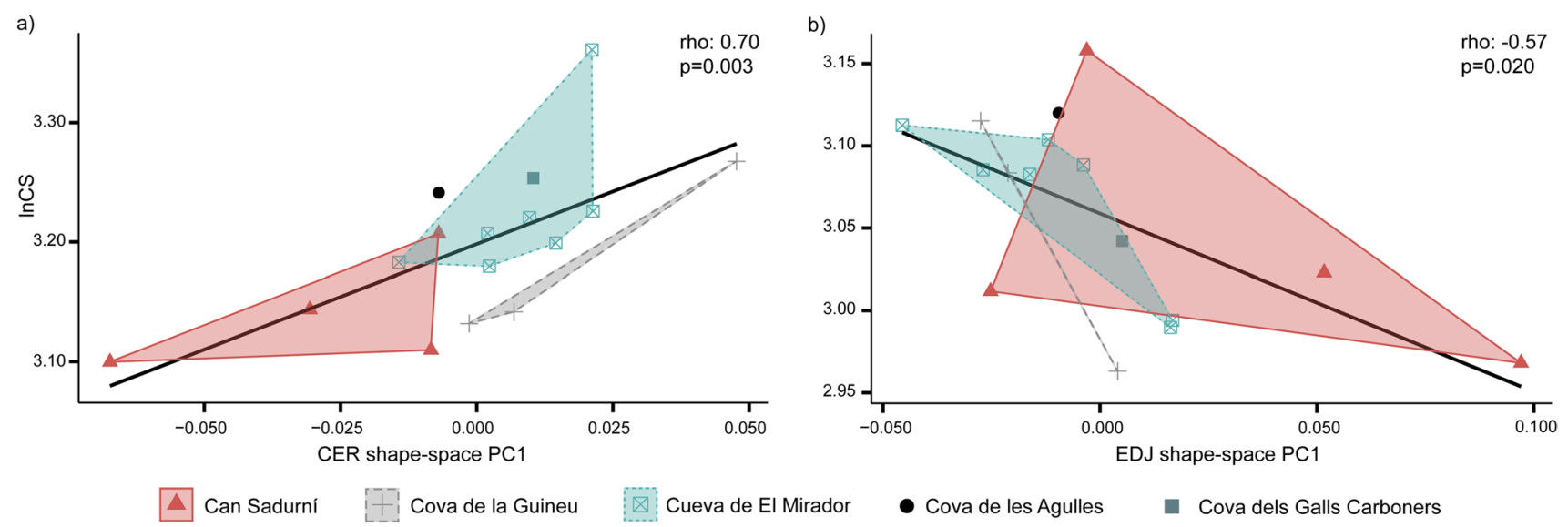

Fig. 5 Shape variation (PC scores) related with size ( $\operatorname{lnCS}$ ) in a) CER and b) EDJ landmark and semilandmark configuration in shape-space analysis. Only significant Spearman correlations were represented 


\section{Discussion}

\section{EDJ variability in the north-eastern and central Iberian Peninsula}

The results obtained here suggest that EDJ morphologies of individuals from Late Neolithic-Chalcolithic sites in the NE and central IP are generally homogeneous. The EDJ morphology of most of the sites overlap in the morphospace, and although it could be affected by a bias due to a small sample, this presumably indicates phenotypic similarity and, hence, biological proximity among samples. However, individuals from the Can Sadurní site present significantly different EDJ morphologies, despite the small sample size, suggesting distant biological affinities with individuals from the same NE-IP area. Specifically, $\mathrm{M}^{1}$ of the Can Sadurní individuals analysed here presented buccolingually larger occlusal trigon area, with horns associated with the protocone and hypocone more lingually oriented and mesio-distally narrower at the cervical area-particularly at the hypoconetogether with relative higher cervical height. This indicates that the Late Neolithic-Chalcolithic Can Sadurní population may be a biologically distinct population. This is in accordance with non-metric dental studies that show that the Late Neolithic-Chalcolithic Can Sadurní population differs from other IP and Mediterranean populations with similar chronologies (Pascual et al. 2018). Previous research has suggested that the people buried at Can Sadurní during the Late Neolithic-Chalcolithic period were part of a closed population based on the high frequency of shovel-shape incisors and enamel hypoplasia documented in them (Carrasco et al. 1989; Blasco 1993; Roca 2012). In this regard, environmental factors, such as malnutrition or systemic disease (which cause most of the enamel hypoplasia (Goodman and Armelagos 1985; Hillson and Antoine 2011), are not totally discarded for understanding Can Sadurní significant EDJ differences. Interestingly, some authors have found a link between the presence of enamel hypoplasia and a greater morphological variability in the later-forming dental traits developed during tooth morphogenesis (e.g. hypocone, extra cusps) in upper molars (Riga et al. 2014). The authors do not suggest a direct link between both traits, but state that both are the result of the same disruptive factor that influence tooth developmental process, and hence the result of more dental morphology diversity. With all the above, dental morphology analyses suggest that people continuously buried throughout the Late Neolithic-Chalcolithic in Can Sadurní might be part of an endogamic group with limited biological relationships with other human groups. But it is also possible that the Can Sadurní individuals may have been part of a descent group that occupied a specific territory, as cultural elements (Vasos de Carena Alta) in common with other pre-coastal Catalan sites have been recovered (Cova Bonica and Fou de Muntaner (Baldellou 1974); Abrics de Sota Penya I, II and IV (Marcet 1981; Petit Mendizábal 1989; Villalba et al. 1989)). Additional analyses including other archaeological sites from the surrounding area (Cova de Can Figueres (Safont and Subirà 1996); Cova de Cassimanya (Edo 1997); Cova Bonica (Baldellou 1974); Marge del Moro (Edo and Artasona 1989)), together with dental remains from the same site attributed to other periods, should shed further light on the hypothesis proposed.

The homogeneity of $\mathrm{M}^{1}$ morphology at other NE and central IP sites agrees with the decrease in genetic variability among the IP population by the Late Neolithic-Chalcolithic and Early Bronze Age, as evidenced by aDNA studies (Szecsenyi-Nagy et al. 2017; Olalde et al. 2018). The population growth during Late Neolithic-Chalcolithic in some areas of the IP, which is instantiated by the increase in the funerary archaeological record, has been suggested as the cause of mobility among communities (Villalba-Mouco et al. 2020). Although the complexity of Late Neolithic-Chalcolithic societies of the northern parts of IP is little understood, transitions to narrower exchange networks, particularly from the Ebro basin (Montes and Alday 2012), together with similar funerary practices (collective burials) and grave-goods analyses, have also been proposed for the cause of the phenotypic similarity among Late Neolithic-Chalcolithic populations from the northern IP (López-Onaindia and Subirà 2017). The exchange of goods and supplies was most probably accompanied by population movements and the admixture between them (Soriano 2017). Taken together, these events may have given rise to the decrease in genetic variability and, consequently, the homogenisation of phenotypic traits such as dental morphology. Although the results obtained here are indicative of the hypothesis posed above, such interpretations must be taken with caution, as we performed an exploratory analysis of the suitability of the method with a small sample size. The inclusion of greater number of Late Neolithic-Chalcolithic samples, especially those found along the Ebro basin and NE-IP (including the Pyrenees area), together with a multi-perspective analysis from other archaeological disciplines, will provide insight into the social complexity of the northern IP during this period.

\section{EDJ as a genetic proxy in Holocene phenotypic affinity studies}

This study also confirms the utility of 3D GM analysis of the EDJ of the first upper molars as an alternative approach in the study of biological and genetic affinities in past human populations, as shown by previous studies (e.g. Monson et al. 2020). The combination of EDJ and cervical outline traits is what significantly differentiated the samples studied here, 
with apparently not significant allometry component-size effect influencing shape-among the individuals analysed. The greatest variability among the samples was found in the shape of the dentine horn associated with the hypocone at the cervical outline, followed by the position of the trigon dentine horns relative to each other on the occlusal surface, both of which allowed us to differentiate one population from another. Although the cervical outline has been successfully used to distinguish between different hominin species (Benazzi et al. 2012; Bailey et al. 2014, 2020) and past human populations (Gamarra et al. 2020), no differences were found between the populations studied here based on cervical traits alone. Nevertheless, the cervical outline, together with occlusal traits analysed separately, exhibited a significant allometric component, which might influence the distribution of the individuals in the morphometric space. Additionally, the high variability in the hypocone shape is also consistent with the developmental tooth formation cascade model (Jernvall and Jung 2000; Salazar-Ciudad and Jernvall 2002) and in accordance with previous studies on human populations (Polychronis and Christou 2013; Morita et al. 2014; Riga et al. 2014; Monson et al. 2020). Since the hypocone is one of the last cusps to form (Hillson 1996), and according with this model, its expression is conditioned by the available time and space left by previous reactiondiffusion signals during cusp formation and their accumulative effects.

Moreover, changes affecting the proximity of these signalling centres are reflected in the relative positions of the cusps and the dentine horn on the occlusal surface. According to this model, the lower mean distances between the main cusps on the developing crown relative to the available space and time allows for the activation of extra enamel knots, and therefore the proliferation of accessory traits on the dental crown (Jernvall and Jung 2000). Several studies have found that specific crown traits, such as relative intercuspal distances and the size of the hypocone, are correlated with Carabelli's trait expression (Romero et al. 2018; Hunter et al. 2010; Guatelli-Steinberg et al. 2013; Moormann et al. 2013; Paul et al. 2017; Scott et al. 2018). These correlations are probably the response to the same underlying morphogenetic mechanisms explained by the morphodynamic model (Moormann et al. 2013). Therefore, the expression of these dental features may covary and probably coevolved, which must be considered in phylogenetic and biological distance approaches that often treat dental characters as independent (Hunter et al. 2010; Salazar-Ciudad and Jernvall 2010; Moormann et al. 2013), such as some non-metric dental studies using discrete traits.

The morphometric analysis of the EDJ has proved an excellent method for the study of biological affinities between NE and central IP populations that is not affected by the interdependence of some discrete dental traits. This approach identifies dental variability among individuals that could not be detected by means of discrete traits on their outer surfaces, which contributes significantly to the field of dental morphology studies. Moreover, we have shown that the morphometric analysis of one dental piece, here the upper first molar, but potentially applicable to the other molar pieces, also provides insights into the relationships between these past human populations. Thus, the study of EDJ shape eliminates the need for several discrete traits from full dentition required in non-metric dental traits analyses for the study of biological affinities (e.g. Coppa et al. 2007; López-Onaindia et al. 2017; Rathmann and Reyes-Centeno 2020). This becomes crucial in fragmentary contexts and collective burials in which the success of the use of several non-metric dental traits depends on their presence in the sample. The analysis of EDJ has also proved useful despite moderate enamel wear, which, by contrast, may mask the expression of discrete dental traits, and thus prevent proper identification. Additionally, despite the small geographical range that is covered by the sample analysed here, the EDJ morphometric analysis have demonstrated to be sensitive enough to detect morphological differences among individuals belonging to populations that were geographically close (sites from NE area). These promising findings open the possibility to further explore populations' biological affinities, and hence population dynamics in a more regional scale.

\section{Conclusions}

The EDJ morphology of the first upper molar has revealed phenotypic similarities among Late Neolithic-Chalcolithic populations from the NE and central Iberian Peninsula, in keeping with the decrease in genetic variability documented in genetic and other dental morphology studies. The EDJ traits of the population buried at the Can Sadurní site differ significantly from those of the nearby populations compared here and the El Mirador cave site (central IP), indicating that they might be a closed group or part of descent group that occupied a specific territory with low levels of admixture. The traits that exhibit the greatest variability are those related to the hypocone area and the distribution of the trigon dentine horns on the occlusal surface.

To sum up, the morphometric analysis of the EDJ has further contributed to our understanding of past human biological affinities and has proved an effective tool for investigating population history in archaeological remains. More importantly, it provides an alternative analysis to traditional genetic studies by means of novel information of dental morphology patterns from human prehistoric populations. The EDJ therefore makes it possible to study human genetic variability while overcoming the drawbacks of aDNA analyses and the enamel dental wear that archaeological remains usually exhibit, as well as the interdependence of some dental 
discrete traits. Moreover, it represents a biological approach that attempts to understand the complexity of past human networks, which together with future studies in other fields will contribute to our understanding of the changes in social complexity that occurred during this time period.

Supplementary Information The online version contains supplementary material available at https://doi.org/10.1007/s12520-021-01499-7.

Acknowledgements We would like to thank Belen Notario Collado from the Microscopy and Micro-Computed Tomography Laboratory of CENIEH for CT scanning and technical assistance. We also thank Manel Prada for assistance for preparing Fig. 1. We thank the associate editor Christina Papageorgopoulou, and two anonymous reviewers for their comments that help to improve the manuscript.

Funding Open Access funding provided thanks to the CRUE-CSIC agreement with Springer Nature. B.G. was supported by the Beatriu de Pinós Post-doctoral fellowship (2017 BP 00210) from Agència de Gestió d'Ajuts Universitaris i de Recerca (AGAUR), Government of Catalonia. A.D.B. is funded by predoctoral Universitat Rovira i Virgili Martí-Franquès Research Grant (URV 2020PMF-PIPF-43). This study was funded by 2017SGR1040 project: Social, cultural and biological Evolution during the Pleistocene (StEP), from AGAUR; and MICINN/FEDER - PGC2018-093925-B-C32 project: Comportamiento eco-social de los homininos de la Sierra de Atapuerca durante el Cuaternario V, from the Spanish Ministry of Science, Innovation and Universities. Can Sadurní radiocarbon dates were obtained within the framework of the project "Genètica i mobilitat al massís del Garraf durant el Neolític 2016-2017” (AP21/16) by Institut Ramón Muntaner, Research Group in Biological Anthropology, Barcelona (GREAB, SGR2017-1630), from AGAUR, and Aproximación a las primeras comunidades neolíticas del Mediterraneo nordoccidental: construyendo respuesta desde los análisis paleoantropológicos y genéticos (HAR2015-67323-C2-1-P from the Spanish Ministry of Science, Innovation and Universities. The Institut Català de Paleoecologia Humana $i$ Evolució Social (IPHES-CERCA) has received financial support from the Spanish Ministry of Science and Innovation through the Maria de Maeztu programme for Units of Excellence (CEX2019-000945-M).

Data availability Digital surfaces of the 3D surface models that support the findings of this study are available at MorphoSource.org.

Code availability The data that support the findings of this study is available at https://doi.org/10.5281/zenodo.5891983.

\section{Declarations}

Competing interests The authors declare no competing interests.

Open Access This article is licensed under a Creative Commons Attribution 4.0 International License, which permits use, sharing, adaptation, distribution and reproduction in any medium or format, as long as you give appropriate credit to the original author(s) and the source, provide a link to the Creative Commons licence, and indicate if changes were made. The images or other third party material in this article are included in the article's Creative Commons licence, unless indicated otherwise in a credit line to the material. If material is not included in the article's Creative Commons licence and your intended use is not permitted by statutory regulation or exceeds the permitted use, you will need to obtain permission directly from the copyright holder. To view a copy of this licence, visit http://creativecommons.org/licenses/by/4.0/.

\section{References}

Adams D, Rohlf FJ, Slice DE (2013) A field comes of age: geometric morphometrics in the 21 st century Geometric morphometrics and the "Procrustes paradigm." Hystrix 24:7-14. https://doi.org/ 10.4404/hystrix-24.1-6283

Al-Shahrani I, Dirks W, Jepson N, Khalaf K (2014) 3D-Geomorphometrics tooth shape analysis in hypodontia. Front Physiol 5:154. https://doi.org/10.3389/fphys.2014.00154

Amante C, Eakins BW (2009) ETOPO1 1 Arc-Minute global relief model: procedures, data sources and analysis. NOAA Technical Memorandum NESDIS NGDC-24. National Geophysical Data Center, NOAA. http//www ngdc noaa gov/mgg/global/ global html

Aubán JB, Puchol OG, Orozco-Köhler T (2018) New insigths relating to the beginning of the Neolithic in the eastern Spain: evaluating empirical data and modelled predictions. Quat Int 470:439-450. https://doi.org/10.1016/j.quaint.2017.03.071

Bailey SE, Benazzi S, Souday C et al (2014) Taxonomic differences in deciduous upper second molar crown outlines of Homo sapiens, Homo neanderthalensis and Homo erectus. J Hum Evol 72:1-9. https://doi.org/10.1016/j.jhevol.2014.02.008

Bailey SE, Sorrentino R, Mancuso G et al (2020) Taxonomic differences in deciduous lower first molar crown outlines of Homo sapiens and Homo neanderthalensis. J Hum Evol 147:102864. https://doi.org/10.1016/j.jhevol.2020.102864

Baldellou V (1974) Los materiales arqueológicos de la" Cova Bonica" de Vallirana (Barcelona). Empúries Rev món clàssic i Anti. tardana 36:1-19

Bastir M, García-Martínez D, Torres-Tamayo N et al (2019) Workflows in a Virtual Morphology Lab: 3D scanning, measuring, and printing. J Anthro Sci 97:107-134. https://doi.org/10.4436/ jass. 97003

Benazzi S, Fornai C, Bayle P et al (2011) Comparison of dental measurement systems for taxonomic assignment of Neanderthal and modern human lower second deciduous molars. J Hum Evol 61:320-326. https://doi.org/10.1016/j.jhevol.2011.04.008

Benazzi S, Fornai C, Buti L et al (2012) Cervical and crown outline analysis of worn Neanderthal and modern human lower second deciduous molars. Am J Phys Anthropol 149:537-546. https:// doi.org/10.1002/ajpa.22155

Blasco A (1996) Organització social, pràctiques funeràries i antropologia física. Intercambio de bienes de prestigio en Catalunya durante el Neolítico. El desarrollo de la desigualdad social. Rubricatum Revista del Museu de Gavà 2: I Congrés del Neolític a la península ibèrica: $549-556$

Blasco A (1993) Les ocupacions prehistòriques de la cova de Can Sadurní (Begues, Baix Llobregat). Postgraduate dissertation, Universitat de Barcelona

Borrell F, Bosch J (2012) Las minas de variscita de Gavà (Barcelona) y las redes de circulación en el Neolítico. Rubricatum Revista del Museu de Gavà 5 Actes del Congrés Internacional Xarxes al Neolític:315-322

Bosch J, Ribé G, Oliva M, Clop X (2012) La exposición xarxes. Els primers intercanvis fa 6.000 anys. Un punto de partida para una síntesis en el Neolitico Catalán. Rubricatum Revista del Museu de Gavà, 5 Actes del Congrés Internacional Xarxes al Neolític:459-466

Butler PM (1956) The ontogeny of molar pattern. Biol Rev 31:30-69

Butler PM (1939) Studies of the Mammalian Dentition.-Differentiation of the Post-canine Dentition. Proc Zool Soc Lond 109:1-36

Carrasco T, Malgosa A, Subirà ME, Castellana C (1989) Estudi dentari de les restes humanes de la cova de Can Sadurní, 
Begues. I Jornades Arqueològiques del Baix Llobregat. Castelldefels:65-72

Castany J (2008) Els megàlits neolítics de" Solsonià". PhD Dissertation, Universitat de Lleida

Cebrià A, Fullola JM, López-Onaindia D et al (2013) La cova sepulcral del pantà de Foix (Castellet i la Gornal). De jaciment arraconat a jaciment modèlic. III Monografies del Foix. Comunicacions de la III Trobada d'Estudiosos del Foix (Castellet i la Gorn. 2012). Documents de Treball. Sèrie Territòri 25:184-194

Ceperuelo D, Lozano M, Duran-Sindreu F, Mercadé M (2014) Root canal morphology of Chalcolithic and Early Bronze age human populations of El Mirador Cave (Sierra de Atapuerca, Spain). Anat Rec 297:2342-2348. https://doi.org/10.1002/ar.22958

Coppa A, Cucina A, Lucci M et al (2007) Origins and spread of agriculture in Italy: a nonmetric dental analysis. Am J Phys Anthropol 133:918-930. https://doi.org/10.1002/ajpa.20620

Cucina A, Lucci M, Vargiu R, Coppa A (1999) Dental evidence of biological affinity and environmental conditions in prehistoric Trentino (Italy) samples from the Neolithic to the Early Bronze Age. Int J Osteoarchaeol 9:404-416. https://doi.org/10.1002/(SICI) 1099-1212(199911/12)9:6\%3c404::AID-OA498\%3e3.0.CO;2-7

Dahlberg AA (1945) The changing dentition of man. J Am Dent Assoc 32:676-690

Daura J, Sanz M, Oms FX et al (2015) La Cova de l'Avi (Vallirana, Barcelona) y el inicio del Neolítico final en el Nordeste de la Península Ibérica. Inhumaciones colectivas y nuevas redes de intercambio. Trabajos de Prehistoria 72:327-341. https://doi.org/ 10.3989/tp.2015.12157

Delgado M, Ramírez LM, Adhikari K et al (2019) Variation in dental morphology and inference of continental ancestry in admixed Latin Americans. Am J Phys Anthropol 168:438-447. https:// doi.org/10.1002/ajpa.23756

Edo M, Gómez-Bach A, Mestres J et al (in press) Jaciments, ritmes i dinàmiques d'implantació i explotació del territori: El litoral Mediterrani i les serralades prelitorals, in El Neolític Antic a Catalunya. Taula Rodona de Girona 2018. Cypsela Revista de prehistòria i protohistòria.

Edo M (1997) Inventari Arqueològic de Begues. L'Eixarmada, Butlletí del Cent d'Estudis Beguetans 2:6

Edo M, Artasona R (1989) La coveta del Marge del Moro, Begues: un enterrament del Neolític Antic. I Jornades Arqueològiques del Baix Llobregat. Castelldefels:112-119.

Edo M, Ferran A, Maria B (2012) Can Sadurní (Begues, Baix Llobregat), de la captación de recursos abióticos al inicio de la mineria de aluminio-fosfatos (10500-4000 Cal Ane) en el Macizo de Garraf. Rubricatum Revista del Museu de Gavà 5:299-306

Fernandes DM, Mittnik A, Olalde I et al (2020) The spread of steppe and Iranian-related ancestry in the islands of the western Mediterranean. Nat Ecol Evol 4:334-345. https://doi.org/10.1038/ s41559-020-1102-0

Fisher RA (1958) Statistical methods for research workers. Oliver and Boyd, Edinburgh and London

Fornai C, Benazzi S, Gopher A et al (2016) The Qesem Cave hominin material (part 2): a morphometric analysis of dm2-QC2 deciduous lower second molar. Quat Int 398:175-189

Fornai C, Bookstein FL, Weber GW (2015) Variability of Australopithecus second maxillary molars from Sterkfontein Member 4. J Hum Evol 85:181-192. https://doi.org/10.1016/j.quaint.2015. 11.102

Frontier S (1976) Étude de la décroissance des valeurs propres dans une analyse en composantes principales: Comparaison avec le modale du bâton brisé. J Exp Mar Bio Ecol 25:67-75. https:// doi.org/10.1016/0022-0981(76)90076-9

Fruciano C (2016) Measurement error in geometric morphometrics. Dev Genes Evol 226:139-158. https://doi.org/10.1007/ s00427-016-0537-4
Gamarra B, McCall A, Del Bove A et al (2020) Dental morphological analysis of Neolithic to Iron Age populations from the Great Hungarian Plain. A Geometric Morphometrics approach. 26th Annual Meeting of the European Association of Archaeologist, Virtual.

García-Martínez de Lagrán Í, Fernández-Domínguez E, Rojo M (2018) Solutions or illusions? an analysis of the palaeogenetic evidence at the origins of the Neolithic in the Iberian Peninsula. Quat Int 470:353-368. https://doi.org/10.1016/j.quaint.2017.07.012

Gibaja J F, Léa V, Luglie C et al (2013) Between Sardinia and Catalonia: contacts and relationships during the Neolithic. In: Blasco E, Francalacci P, Nocentini A, Tanda G (eds) Iberia e Sardegna. Legami linguistici, archeologici e genetici dal Mesolitico all'Età del Bronzo. Le Monnier-Mondadori Education, Firenze, pp. 214-233.

Gibaja JF, Duboscq S, Morell B et al (2018) Symbolism, exchange and differential grave building efforts during the Neolithic of the North-eastern Iberian Peninsula. The Necropolis of Bòbila Madurell-Can Gambús 1-2: An example of unequal objects and grave goods Distribution. In: Cruz A, Gibaja, JF (eds) Interchange in Pre-and Protohistory: Case Studies in Iberia, Romania, Turkey and Israel. BAR International series 2891, Oxford, pp. 69-82.

Gibaja JF, Majó T, Chambon P et al (2010) Prácticas funerarias durante el Neolítico. Los enterramientos infantiles en el noreste de la Península Ibérica. Complutum, 21 (2), 47-68.

Gómez-Robles A, Martinón-Torres M, Bermúdez de Castro JM et al (2007) A geometric morphometric analysis of hominin upper first molar shape. J Hum Evol 53:272-85. https://doi.org/10. 1016/j.jhevol.2007.02.002

Gómez-Robles A, Bermúdez de Castro JMB, Martinón-Torres M et al (2012) A geometric morphometric analysis of hominin upper second and third molars, with particular emphasis on European Pleistocene populations. J Hum Evol 63:512-526. https://doi.org/10.1016/j.jhevol.2012.06.002

Gómez A, Tornero C, Borrell F et al (2008) Un ejemplo de cavidad sepulcral del Neolítico final en la costa nordeste peninsular: la cueva de las Agulles (Corbera de Llobregat, Baix Llobregat). In: Hernández M, Soler J, López JA (coords) IV Congreso del Neolítico Peninsular (Alicante, 2006). Museo Arqueológico de Alicante, Diputación de Alicante, Alicante, pp. 92-97

Goodman AH, Armelagos GJ (1985) Factors affecting the distribution of enamel hypoplasias within the human permanent dentition. Am J Phys Anthropol 68:479-493. https://doi.org/10. 1002/ajpa.1330680404

Guatelli-Steinberg D, Hunter JP, Durner RM et al (2013) Teeth, morphogenesis, and levels of variation in the human Carabelli trait. In: Scott GR, Irish JD (eds) Anthropological Perspectives on Tooth Morphology. Genetics, Evolution, Variation. Cambridge University Press, Cambridge, pp. 69-91.

Gunz P, Mitteroecker P (2013) Semilandmarks: a method for quantifying curves and surfaces. Hystrix, Ital J Mammal 24:103-109. https://doi.org/10.4404/hystrix-24.1-6292

Gunz P, Mitteroecker P, Bookstein FL (2005) Semilandmarks in three dimensions. In: Slice DE (ed) Modern Morphometrics in Physical Anthropology. Springer, Boston, pp 73-98

Hanegraef H, Martinón-Torres M, Martínez de Pinillos M et al (2018) Dentine morphology of Atapuerca-Sima de los Huesos lower molars: evolutionary implications through three-dimensional geometric morphometric analysis. Am J Phys Anthropol 166:276-295. https://doi.org/10.1002/ajpa.23428

Hervella M, Izagirre N, Alonso S et al (2012) Ancient DNA from hunter-gatherer and farmer groups from Northern Spain supports a random dispersion model for the Neolithic expansion into Europe. PLoS One 7:e34417. https://doi.org/10.1371/journ al.pone. 0034417 
Hillson S (2005) Teeth. Cambridge University Press, Cambdrige Hillson S (1996) Dental anthropology. Cambridge University Press, Cambridge

Hillson S, Antoine D (2011) The mechanisms that produce the defects of enamel hypoplasia. In: American Journal of Physical Anthropology. Wiley-Blackwell, S52:163.

Horwath BC, Waterman AJ, Lillios KT, Irish JD (2014) Assessing change in diet and biological affinity between the 4th and 3rd millennia cal BCE in the Portuguese Estremadura: a preliminary dental comparison of Feteira II and Bolores. HOMOJournal Comp Hum Biol 65:87-100. https://doi.org/10.1016/j. jchb.2013.11.003

Hublin J-J, Ben-Ncer A, Bailey SE et al (2017) New fossils from Jebel Irhoud, Morocco and the pan-African origin of Homo sapiens. Nature 546:289. https://doi.org/10.1038/nature22336

Hunter JP, Guatelli-Steinberg D, Weston TC et al (2010) Model of tooth morphogenesis predicts Carabelli cusp expression, size, and symmetry in humans. PLoS One 5:e11844. https://doi.org/ 10.1371/journal.pone.0011844

Irish D, Joel D (2005) Population continuity vs. discontinuity revisited: dental affinities among late Paleolithic through Christian-era Nubians. Am J Phys Anthropol 128:520-535. https://doi.org/10. 1002/ajpa.20109

Jernvall J, Jung H (2000) Genotype, phenotype, and developmental biology of molar tooth characters. Am J Phys Anthropol 113:171-190. https://doi.org/10.1002/1096-8644(2000)43:31+\% 3c171::AID-AJPA6\%3e3.0.CO;2-3

Klingenberg CP (2016) Size, shape, and form: concepts of allometry in geometric morphometrics. Dev Genes Evol 226:113-137. https:// doi.org/10.1007/s00427-016-0539-2

Kraus BS, Jordan RE (1965) The human dentition before birth. Lea \& Febiger, Philadelphia

Krenn VA, Fornai C, Wurm L et al (2019) Variation of 3D outer and inner crown morphology in modern human mandibular premolars. Am J Phys Anthropol 169:646-663. https://doi.org/10.1002/ ajpa. 23858

Le Luyer M, Bayle P (2017) Microevolution of outer and inner structures of upper molars in Late Pleistocene and Early Holocene humans. Comptes Rendus Palevol 16:632-644. https://doi.org/ 10.1016/j.crpv.2016.11.009

Le Luyer M, Coquerelle M, Rottier S, Bayle P (2016) Internal tooth structure and burial practices: insights into the Neolithic necropolis of Gurgy (France, 5100-4000 cal. BC). PLoS One 11:e0159688. https://doi.org/10.1371/journal.pone.0159688

López-Onaindia D, Coca M, Gibaja JF, Subirà ME (2017) Biological differences related to cultural variability during the Neolithic in a micro-geographical area of the Iberian Peninsula. Archaeol Anthropol Sci 10:1957-1969. https://doi.org/10.1007/ s12520-017-0515-4

López-Onaindia D, Subirà ME (2017) Prehistoric funerary complexity in northern Iberia studied by using dental morphology. HOMOJournal Comp Hum Biol 68:122-133. https://doi.org/10.1016/j. jchb.2017.03.002

MacArthur RH (1957) On the relative abundance of bird species. Proc Natl Acad Sci U S A 43:293. https://doi.org/10.1073/pnas.43.3. 293

Marcet R (1981) El Neolític Antic (Cardial-Epicardial) a Catalunya. In: Institut de Prehistòria i Arqueologia (ed) El Neolític a Catalunya. Taula Rodona de Montserrat 1980. Publicacions Abadia Montserrat, pp 15-31

Martin A (2003) Els grups del neolític final, calcolític i bronze antic: Els inicis de la metal lúrgia. Cota zero: Revista d'Arqueologia i Ciència 18:76-105

Martin RMG, Hublin J-J, Gunz P, Skinner MM (2017) The morphology of the enamel-dentine junction in Neanderthal molars: gross morphology, non-metric traits, and temporal trends. J Hum Evol 103:20-44. https://doi.org/10.1016/j.jhevol.2016.12.004

Martinón-Torres M, Bastir M, Bermúdez de Castro JM et al (2006) Hominin lower second premolar morphology: evolutionary inferences through geometric morphometric analysis. J Hum Evol 50:523-33. https://doi.org/10.1016/j.jhevol.2005.12.004

Martins H, Oms FX, Pereira L et al (2015) Radiocarbon dating the beginning of the Neolithic in Iberia: new results, new problems. J Mediterr Archaeol 28:105-131. https://doi.org/10.1558/jmea. v28i1.27503

Molnar S (1971) Human tooth wear, tooth function and cultural variability. Am J Phys Anthropol 34:175-189

Monson TA, Fecker D, Scherrer M (2020) Neutral evolution of human enamel-dentine junction morphology. Proc Natl Acad Sci 117:26183-26189. https://doi.org/10.1073/pnas.2008037117

Montes L, Alday A (2012) Enredados en la malla neolítica de la cuenca del río Ebro. Redes, continuidades y cambios. Rubricatum Revista del Museu de Gavà, 5 Actes del Congrés Internacional Xarxes al Neolític: 51-60.

Moormann S, Guatelli-Steinberg D, Hunter J (2013) Metamerism, morphogenesis, and the expression of Carabelli and other dental traits in humans. Am J Phys Anthropol 150:400-408. https://doi. org/10.1002/ajpa.22216

Morita W, Yano W, Nagaoka T et al (2014) Patterns of morphological variation in enamel-dentin junction and outer enamel surface of human molars. J Anat 224:669-680. https://doi.org/10.1111/ joa. 12180

Olalde I, Brace S, Allentoft ME et al (2018) The Beaker phenomenon and the genomic transformation of northwest Europe. Nature 555:190-196. https://doi.org/10.1038/nature25738

Olalde I, Mallick S, Patterson N et al (2019) The genomic history of the Iberian Peninsula over the past 8000 years. Science 363:1230 1234. https://doi.org/10.1126/science.avv4040

Olalde I, Schroeder H, Sandoval-Velasco M et al (2015) A common genetic origin for early farmers from Mediterranean Cardial and Central European LBK cultures. Mol Biol Evol 32:3132-3142. https://doi.org/10.1093/molbev/msv181

Olejniczak A, Smith T, Feeney R et al (2008) Dental tissue proportions and enamel thickness in Neandertal and modern human molars. J Hum Evol 55:12-23. https://doi.org/10.1016/j.jhevol. 2007.11.004

Oms FX, Martín A, Esteve X et al (2016) The Neolithic in northeast Iberia: chronocultural phases and 14C. Radiocarbon 58:291. https://doi.org/10.1017/RDC.2015.14

Oms FX, Terradas X, Morell B, Gibaja JF (2018) Mesolithic-Neolithic transition in the northeast of Iberia: Chronology and socioeconomic dynamics. Quat Int 470:383-397. https://doi.org/10. 1016/j.quaint.2017.06.003

Ortiz A, Bailey SE, Hublin J, Skinner MM (2017) Homology, homoplasy and cusp variability at the enamel-dentine junction of hominoid molars. J Anat 231:585-599. https://doi.org/10.1111/ joa. 12649

Pascual I, López-Onaindia D, Gibaja JF, Subirà ME (2018) La població neolítica barcelonina des de la morfologia dental. Dades de la població de la serralada prelitoral. Cypsela Revista de prehistòria i protohistòria 21:23-41

Paul KS, Astorino CM, Bailey SE (2017) The Patterning Cascade Model and Carabelli's trait expression in metameres of the mixed human dentition: exploring a morphogenetic model. Am J Phys Anthropol 162:3-18. https://doi.org/10.1002/ajpa.23080

Peña-Chocarro L, Pérez-Jordà G, Morales J (2018) Crops of the first farming communities in the Iberian Peninsula. Quat Int 470:369382. https://doi.org/10.1016/j.quaint.2017.06.002 
Petit Mendizábal MA (1989) El poblament de l'Edat del Bronze al Baix Llobregat. I Jornades Arqueològiques del Baix Llobregat. Castelldefels:121-139.

Polychronis G, Christou P (2013) Geometric morphometric 3D shape analysis and covariation of human mandibular and maxillary first molars. Am J Phys Anthropol 152:186-196. https://doi.org/10. 1002/ajpa.22340

Prado-Simón L, Martinón-Torres M, Baca P et al (2012) Three-dimensional evaluation of root canal morphology in lower second premolars of early and Middle Pleistocene human populations from Atapuerca (Burgos, Spain). Am J Phys Anthropol 147:452-461. https://doi.org/10.1002/ajpa.22015

Profico A, Schlager S, Valoriani V et al (2018) Reproducing the internal and external anatomy of fossil bones: two new automatic digital tools. Am J Phys Anthropol 166:979-986. https://doi.org/ 10.1002/ajpa.23493

R Core Team, 2020. R: A language and environment for statistical computing. R Foundation for Statistical Computing, Vienna, Austria.

Rathmann H, Reyes-Centeno H (2020) Testing the utility of dental morphological trait combinations for inferring human neutral genetic variation. Proc Natl Acad Sci 117:10769-10777. https:// doi.org/10.1073/pnas.1914330117

Riga A, Belcastro MG, Moggi-Cecchi J (2014) Environmental stress increases variability in the expression of dental cusps. Am J Phys Anthropol 153:397-407. https://doi.org/10.1002/ajpa.22438

Roca N (2012) Aproximació a les pràctiques funeràries al Neolític Final - Calcolític. Estudi de les peces dentàries de les capes $8 \mathrm{i}$ 9 de Can Sadurní. Master Dissertation, Universitat Autònoma de Barcelona.

Roig J, Coll JM, Gibaja JF et al (2010) La necrópolis de Can Gambús-1 (Sabadell, Barcelona) nuevos conocimientos sobre las prácticas funerarias durante el Neolítico medio en el noreste de la Península Ibérica. Trabajos de Prehistoria 67:59-84. https://doi.org/ 10.3989/tp.2010.10031

Rojo-Guerra MA, de Lagrán ÍG-M, Royo-Guillén JI (2018) The beginning of the Neolithic in the mid-Ebro valley and in Iberia's inland (northern and southern Submeseta), Spain. Quat Int 470:398438. https://doi.org/10.1016/j.quaint.2017.12.037

Romero A, Torrijo-Boix S, Gómez-Torres M et al (2018) Cúspide de Carabelli y variación morfomètrica del diente. In: Malgosa A, Aluja MP (eds) La Antropología física en la era de la Genómica. Universitat Autònoma de Barcelona, Barcelona, pp 346-352

Ruiz J, Muncunill J, Fontanals-Coll M, Subirà ME (2012) Morfología dental en poblaciones mesolíticas y neolíticas del Mediterrámeo. Una aproximación a las relaciones filogenéticas entre poblaciones mesolíticas y neolíticas del levante peninsular a partir de la morfología dental. Rubricatum Revista del Museu de Gavà, 5 Actes del Congrés Internacional Xarxes al Neolític:79-86.

Safont S, Subirà ME (1996) Organització social, pràctiques funeràries i antropologia física. Estudio antropológico de diversos hallazgos en la cueva de Can Figueres (Baix Llobregat). Rubricatum Revista del Museu de Gavà, 2 I Congrés del Neolític a la península ibèrica:575-580.

Salazar-Ciudad I, Jernvall J (2002) A gene network model accounting for development and evolution of mammalian teeth. Proc Natl Acad Sci 99:8116-8120. https://doi.org/10.1073/pnas.13206 9499

Salazar-Ciudad I, Jernvall J (2010) A computational model of teeth and the developmental origins of morphological variation. Nature 464:583-586. https://doi.org/10.1038/nature08838

Schlager S (2017) Morpho and Rvcg-Shape Analysis in R: R-Packages for geometric morphometrics, shape analysis and surface manipulations. In: Zheng G, Li S, Székely, GBT (eds) Statistical Shape and Deformation Analysis. Elsevier, pp. 217-256. https://doi.org/ 10.1016/B978-0-12-810493-4.00011-0
Scott G, Turner C (2008) History of dental anthropology. In: Irish J, Nelson G (eds) Technique and Application in Dental Anthropology. Cambridge University Press, New York, pp 10-34. https:// doi.org/10.1017/CBO9780511542442.002

Scott GR, Anta A, Schomberg R, De la Rua C (2013) Basque dental morphology and the "Eurodont" dental pattern. In: Scott GR, Irish JD (eds) Anthropological Perspective on tooth morpholog: Genetics, evolution, variation. Cambridge University Press, New York, pp 296-318. https://doi.org/10.1017/CBO9780511984464. 013

Scott GR, Turner II CG, Townsend GC, Martinón-Torres M (2018) The anthropology of modern human teeth: dental morphology and its variation in recent and fossil Homo sapiens, 2nd edn. Cambridge University Press, Cambridge. https://doi.org/10.1017/ 9781316795859

Skinner MM, de Vries D, Gunz P et al (2016) A dental perspective on the taxonomic affinity of the Balanica mandible (BH-1). J Hum Evol 93:63-81. https://doi.org/10.1016/j.jhevol.2016.01.010

Skinner MM, Evans A, Smith T et al (2010) Brief communication: contributions of enamel-dentine junction shape and enamel deposition to primate molar crown complexity. Am J Phys Anthropol 142:157-63. https://doi.org/10.1002/ajpa.21248

Skinner MM, Gunz P, Wood BA, Hublin J-J (2008) Enamel-dentine junction (EDJ) morphology distinguishes the lower molars of Australopithecus africanus and Paranthropus robustus. J Hum Evol 55:979-988. https://doi.org/10.1016/j.jhevol.2008.08.013

Skinner MM, Wood BA, Boesch C et al (2008) Dental trait expression at the enamel-dentine junction of lower molars in extant and fossil hominoids. J Hum Evol 54:173-86. https://doi.org/10.1016/j. jhevol.2007.09.012

Smith T, Olejniczak A (2012) Variation in enamel thickness within the genus Homo. J Hum Evol 62:395-411. https://doi.org/10.1016/j. jhevol.2011.12.004

Smith TM, Olejniczak AJ, Reid DJ et al (2006) Modern human molar enamel thickness and enamel-dentine junction shape. Arch Oral Biol 51:974-995. https://doi.org/10.1016/j.archoralbio.2006.04. 012

Soriano I (2017) Les pràctiques funeràries durant el calcolític i el bronze antic i mitjà. La fi és el principi Barcelona marc. In: Bosch J, Borrell M, Garrido AM (eds) La fi és el principi. Pràctiques funeràries a la Catalunya prehistòrica. Museu d'Arqueologia de Catalunya/Arqueoxarxa/Departament de Cultura. Generalitat de Catalunya, pp. 79-101.

Sorrentino R, Belcastro MG, Figus C et al (2020) Exploring sexual dimorphism of the modern human talus through geometric morphometric methods. PLoS One 15:e0229255. https://doi.org/10. 1371/journal.pone.0229255

Subirà ME, López-Onaindia D, Y11 R (2016) Cultural changes in funeral rites during the Neolithic in the Northeast of the Iberian Peninsula? The cave of Pantà de Foix (Barcelona). Int J Osteoarchaeol 26:104-113. https://doi.org/10.1002/oa.2400

Szecsenyi-Nagy A, Roth C, Brandt G et al (2017) The maternal genetic make-up of the Iberian Peninsula between the Neolithic and the Early Bronze Age. Sci Rep 7:15644. https://doi.org/10.1038/ s41598-017-15480-9

Terradas X, Gratuze B, Bosch J et al (2014) Neolithic diffusion of obsidian in the western Mediterranean: new data from Iberia. $\mathbf{J}$ Archaeol Sci 41:69-78. https://doi.org/10.1016/j.jas.2013.07.023

Townsend G, Bockmann M, Hughes T, Brook A (2012) Genetic, environmental and epigenetic influences on variation in human tooth number, size and shape. Odontology 100:1-9. https://doi.org/10. 1007/s10266-011-0052-z

Townsend G, Harris EF, Lesot H et al (2009) Morphogenetic fields within the human dentition: a new, clinically relevant synthesis of an old concept. Arch Oral Biol 54:S34-S44. https://doi.org/ 10.1016/j.archoralbio.2008.06.011 
Villalba-Mouco V, Bea M, Montes L, Salazar-García DC (2020) Mobility across the pre-Pyrenean mountain ranges during the Chalcolithic through strontium isotopes in human enamel: La Cueva de los Cristales (Sarsa de Surta, Huesca, Spain). J Archaeol Sci Reports 31:102343. https://doi.org/10.1016/j.jasrep.2020.102343

Villalba MJ, Blasco A, Edo M (1989) La Prehistoria al Baix Llobregat. Estat de la qüestió. I Jornades Arqueològiques del Baix Llobregat. Castelldefels: 7-41.

Villalba MJ, Edo M, Blasco A (2011) Les mines neolítiques de Can Tintorer. Una relectura trenta anys després. In: Blasco A, Edo M, Villalba MJ (eds) La cova de Can Sadurní i la prehistòria de Garraf. Recull de 30 anys d'investigació. EDAR Hugony Editore, pp 293-333

Weller O, Fíguls A (2012) Los intercambios a media y larga distancia y el rol de la sal en el Neolítico medio en el Altiplano y Prepirineo central catalán. Rubricatum Revista del Museu de Gavà 5 Actes del Congrés Internacional Xarxes del Neolític: 201-212

Wessel P, Smith WHF (1998) New, improved version of Generic Mapping Tools released. Eos, Trans Am Geophys Union 79:579. https://doi.org/10.1029/98EO00426
Zanolli C, Martinón-Torres M, Bernardini F et al (2018) The Middle Pleistocene (MIS 12) human dental remains from Fontana Ranuccio (Latium) and Visogliano (Friuli-Venezia Giulia), Italy. A comparative high resolution endostructural assessment. PLoS One 13:e0189773. https://doi.org/10.1371/journal.pone.0189773

Zelditch ML, Swiderski DL, Sheets HD (2012) Geometric Morphometrics for Biologists: A primer, 2nd edn. Academic Press, London

Scott GR, Turner C (1997) Anthropology of Modern Human Teeth: Dental Morphology and its Variation in Recent Human Populations. Cambridge University Press, Cambdrige

Portney, L. G., \& Watkins, M. P. (2009). Foundations of clinical research: applications to practice (Vol. 892). Upper Saddle River, NJ: Pearson/Prentice Hall.

Publisher's note Springer Nature remains neutral with regard to jurisdictional claims in published maps and institutional affiliations. 